Studies in Philosophy

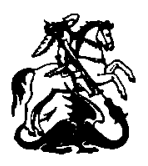






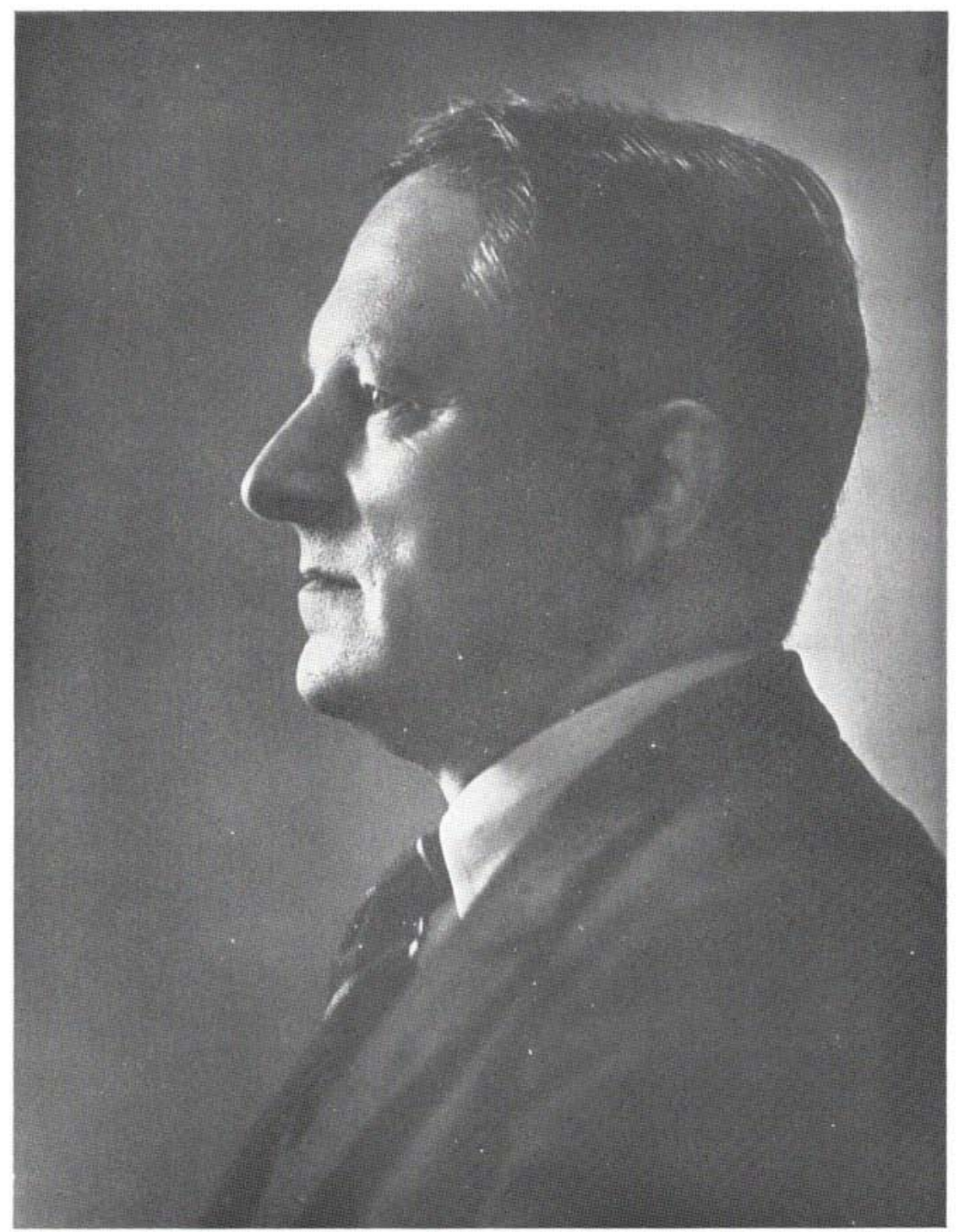

R. A. HOERNLÉ 


\title{
Studies in Philosophy
}

\section{REINHOLD FRIEDRICH ALFRED HOERNLÉ}

\author{
EDITED AND WITH A MEMOIR BY \\ DANIEL S. ROBINSON \\ Director of the School of Philosophy of the \\ University of South California
}

\section{HARVARD UNIVERSITY PRESS \\ Cambridge}


FIRST PUBLISHED IN $195^{2}$

All rights reserved

PRINTED IN GREAT BRTTAIN

in I I point Baskerville type

BY T. AND A. CONSTABLE LTD.

Printers to the University of Edinburgh 
THE HERBERT WILDON CARR

PUBLICATION FUND OF

THE UNIVERSITY OF SOUTHERN CALIFORNIA

THE late Professor Herbert Wildon Carr served on the Faculty of the University of Southern California from I925 until his death in $193 \mathrm{I}$. He bequeathed to the University a sum of money to be used to subsidise the publication of meritorious works on philosophy. This fund has been designated the Herbert Wildon Carr Publication Fund.

The late Professor Reinhold Friedrich Alfred Hoernlé served as Visiting Professor on the Faculty of the School of Philosophy during the academic year 1930-31. He left a number of important essays that have never been published. Arrangements have been made with Messrs. George Allen and Unwin Ltd. to issue this material, together with some other significant essays of Professor Hoernlé.

The School of Philosophy of the University of South California has been signally honoured by having had these two distinguished British scholars as members of its faculty. We deem it especially appropriate to assist with a subvention from Dr. Carr's bequest in the publication of these original and creative philosophical essays of Professor Hoernlé.

Albert S. Raubenheimer

Educational Vice-President

DANiEL S. RoBinson

Director of the School of Philosophy 
